\title{
MAIN TRENDS IN THE RUSSIAN EXPORT OF DIRECT INVESTMENT
}

\author{
A.Pakhomov
}

Despite uncertainty in the global economy and domestic problems of the Russian economy, the export of direct investments from Russia keeps growing. Generally, a large-scale withdrawal of the enterprise capital from the country has a contradictory - both positive and negative - effect on national reproduction processes and is ambiguously assessed by Russian scientific and research community so it requires an in-depth analysis.

In the beginning of the last decade, in Russia explosive growth in export of direct investments was registered, while at present large-scale business activities by public and private companies have become typical of the Russian economy. At the current stage of globalization, efficient development of the national economy is impossible without a real export of the enterprise capital which ensures an optimal way of securing resources which are in short supply, production factors, as well as materialization of potential advantages of domestic companies and the economy as a whole. Implementation of the above conditions creates prerequisites for raising a competitiveness edge on the corporate, sectorial and national levels.

Though a large-scale and sustained withdrawal of the enterprise capital from the country started only in the mid of the last decade (that is, less than 10 years ago) (Table 1), as regards the total volume of the export of direct foreign investments (DFI) in 2012 the Russian Federation was rated the $8^{\text {th }}$ in the world (in accordance with the updated data of the UNCTAD), while its unit weight in the global flow of direct investments amounted to $3.7 \%$ as compared to the $27^{\text {th }}$ position and the share of $0.3 \%$ in $2000^{1}$.

As a result, after the 2008-2009 crisis, Russia has consolidated its position among the world's ten largest producers of direct foreign investments (DFI), while from 2009 it has become a net exporter of the enterprise capital. In the three quarters of 2013, the recordhigh export of direct foreign investments (\$89bn) was registered though the above index is a general one

1 Calculated by the author on the basis of the data of the World Investment Report 2013. Global Value Chains: Investment and Trade for Development, UNCTAD, Geneva, 2013, p. 218-220. which includes, in particular, a diversified deal on purchase by Rosneft of the TNK-BP's assets².

Generally, the extent of Russia's involvement in the trans-border capital movement in the post-crisis period is well ahead of other indices of the country's positioning in the international exchange (the export of goods, services and technologies). The above situation points to strengthening of the investment component of Russia's participation in globalization processes. (Table 2).

It is to be noted that business activities by Russian companies abroad have an ambiguous effect on the country's economic growth. For that reason, an indepth analysis of the causal effect of the export of direct investments and such Russian business's activities abroad as are related to $\mathrm{DFI}$, as well as their effect on reproduction processes in individual industries and sectors of the Russian economy is required.

The activities of the Russian business abroad have the specifics of their own (reasons for export of DFI, methods and spheres of application of the capital abroad and the specifics of relations with state) and differ from incentive motives of trans-border deals and projects carried out by companies from developed countries and states with a dynamically developing economy.

It is to be noted that one should take into account that there are virtually no "attractive" opportunities for making investments in Russia; among exporters of DFl energy and primary sector companies which determine the main lines and areas of investments by Russian multinational corporations on the global level prevail and decisions on

2 The operating data of the Central Bank of the Russian Federation.

\section{DYNAMICS OF DIRECT INVESTMENTS FROM RUSSIA AND THE ACCUMULATED INVESTMENTS ABROAD} IN THE 1992-2012 PERIOD (BILLION USD)

\begin{tabular}{|l|c|c|c|c|c|c|c|c|c|}
\hline & 1992 & 1995 & 2000 & 2005 & 2008 & 2009 & 2010 & 2011 & 2012 \\
\hline Export of DFI & 1,566 & 0,606 & 3,177 & 12,767 & 55,540 & 43,632 & 51,697 & 67,283 & 51,058 \\
\hline Accumulated DFI road & 2,301 & 3,346 & 20,141 & 146,679 & 370,129 & 302,542 & 366,301 & 362,101 & 387,217 \\
\hline
\end{tabular}

Source: the data of the Central bank of Russia and the UNCTADstat for the respective year. 
THE POSITION OF THE RUSSIAN FEDERATION IN THE INTERNATIONAL EXCHANGE OF GOODS, SERVICES AND DFI FLOW IN THE 2000-2012 PERIOD

\begin{tabular}{|l|c|c|c|c|c|c|c|c|}
\hline Index & 2000 & 2005 & 2007 & 2008 & 2009 & 2010 & 2011 & 2012 \\
\hline GDP volume & $17 / 0.8$ & $12 / 2.1$ & $10 / 1.3$ & $8 / 2.8$ & $12 / 2.1$ & $11 / 2.4$ & $10 / 2.8$ & $9 / 2.8$ \\
\hline Export of goods & $17 / 1.7$ & $13 / 2.4$ & $12 / 2.5$ & $9 / 2.9$ & $13 / 2.4$ & $12 / 2.6$ & $9 / 2.9$ & $9 / 2.8$ \\
\hline Import of goods & $29 / 0.7$ & $19 / 1.2$ & $16 / 1.6$ & $16 / 1.8$ & $17 / 1.5$ & $18 / 1.6$ & $17 / 1.8$ & $16 / 1.8$ \\
\hline Export of services & $31 / 0.7$ & $26 / 1.1$ & $25 / 1.2$ & $22 / 1.3$ & $22 / 1.3$ & $23 / 1.2$ & $22 / 1.3$ & $22 / 1.3$ \\
\hline Import of services & $22 / 1.2$ & $17 / 1.6$ & $16 / 1.9$ & $16 / 2.2$ & $16 / 1.9$ & $16 / 2.0$ & $15 / 2.3$ & $14 / 2.3$ \\
\hline Export of DFI & $27 / 0.3$ & $17 / 1.4$ & $14 / 2.0$ & $12 / 2.8$ & $7 / 4.2$ & $8 / 3.8$ & $7 / 4.0$ & $8 / 3.7$ \\
\hline DFI accumulated abroad & $28 / 0.3$ & $15 / 1.1$ & $13 / 1.9$ & $15 / 1.3$ & $15 / 1.3$ & $13 / 1.8$ & $14 / 1.7$ & $17 / 1.8$ \\
\hline Import of DFI & $37 / 0.2$ & $15 / 1.2$ & $10 / 1.8$ & $5 / 4.1$ & $6 / 3.8$ & $8 / 3.3$ & $9 / 3.5$ & $9 / 3.4$ \\
\hline DFI accumulated in the country & $27 / 0.4$ & $17 / 1.6$ & $10 / 2.7$ & $18 / 1.4$ & $18 / 1.4$ & $15 / 2.5$ & $15 / 2.2$ & $16 / 2.2$ \\
\hline
\end{tabular}

Note. The first figure means the place in the international rating, while the second one, the world share (\%) as regards the concrete index.

Source: the author's calculations on the basis of the data of the IMF, the WTO and the UNCTAD for the respective year.

expansion abroad made by owners of large Russian companies are of a subjective nature (Table 3$)^{1}$.

The large-scale and sustained export of direct investments is a relative advantage of Russia on the world market. The effect of that factor is to be taken into account in development of a state policy strategy and transformed into the country's new competitive advantage on foreign markets.

At the current stage, under the effect of the rapidly changing situation on global commodity and financial markets, as well as the economic situation in Russia the following new trends both in export of direct in-

1 For more details see: A.A. Pakhomov. The Export of Direct Investments from Russia: Essays on Theory and Practice - Moscow. The Gaidar Institute, Delo, 2012. p. 368 vestments from Russia and multi-field activities of Russian business abroad are being formed:

- Strengthening of the role of state corporations and companies (Gasprom, Rosneft, RusHydro, Gasprom Neft, Rosatom, RZhD and other) in purchasing of assets and implementation of new projects abroad;

- Reorganization of assets and modification of the corporate strategy of large private multinational corporations (Severstal, Lukoil, Evraz and other);

- Stepping up of activities by state-owned banks in different segments of financial markets of the $\mathrm{CIS}$ (the VTB and the Bank for Foreign Economic Affairs) and far abroad (Sberbank);

Table 3

REPRESENTATION OF RUSSIAN COMPANIES IN THE 100 TOP LIST OF NON-FINANCIAL MULTINATIONAL CORPORATIONS FROM DEVELOPING ECONOMIES AS REGARDS THE VOLUME OF FOREIGN ASSETS IN 2011

\begin{tabular}{|c|c|c|c|c|c|c|c|}
\hline \multirow[b]{2}{*}{ Company } & \multirow[b]{2}{*}{ Sector } & \multicolumn{2}{|c|}{ Position in the rating } & \multicolumn{3}{|c|}{$\begin{array}{l}\text { Performance abroad } \\
\text { (million USD) }\end{array}$} & \multirow[b]{2}{*}{$\mathrm{TNI}^{*}(\%)$} \\
\hline & & $\begin{array}{l}\text { As regards the } \\
\text { volume of for- } \\
\text { eign assets }\end{array}$ & $\begin{array}{l}\text { As regard the } \\
\text { TNI level* }\end{array}$ & assets & sales & $\begin{array}{c}\text { Number of the } \\
\text { employed } \\
\text { (persons) }\end{array}$ & \\
\hline Vympelcom & Telecommunications & 9 & 53 & 29829 & 11280 & 34479 & 54 \\
\hline Lukoil & Oil and gas & 11 & 67 & 29159 & $\begin{array}{l}108 \\
976\end{array}$ & 18144 & 43 \\
\hline Gasprom & Oil and gas & 28 & 85 & 15789 & 91434 & 25900 & 22 \\
\hline Evraz & Metallurgy & 55 & 65 & 8281 & 9766 & 24640 & 43 \\
\hline Severstal & Metallurgy & 57 & 84 & 7638 & 1630 & 11557 & 23 \\
\hline Mechel & Metallurgy & 65 & 80 & 6363 & 6817 & 11983 & 33 \\
\hline AFK Sistema & Telecommunications & 74 & 95 & 5223 & 2512 & 19663 & 11 \\
\hline RUSAL & Metallurgy & 78 & 76 & 4610 & 9706 & 7100 & 36 \\
\hline
\end{tabular}

* TNI is the index of trans-nationality calculated as the average of the following three indices: the ratio of the cost of foreign assets to the total assets, the ratio of foreign sales to the aggregate sales and the ratio of the number of workers employed at branches abroad to the total number of the corporation's employees. The TNI index points to the extent of importance of the company's foreign operations and that of operations by foreign branches on foreign markets to a multinational corporation. The higher the index, the higher importance of activities of foreign branches to the company.

Source: UNCTAD World investment Report 2013. Geneva, Country Fact Sheet: Russian Federation, Presence in the top-100 nonfinancial TNCs from developing countries, ranked by foreign assets, 2011, p. 2. 
- Diversification of activities of the "second echelon" of Russian multinational companies (Summa Group, Inter RAO, Tatneft and other), private investment funds, individuals, as well as mid-sized companies and companies beyond the primary sector;

- Utilization of mixed forms of investment (asset swap, nonmonetary deals, strategic partnership and other);

- Growth in the number of purchases in energy and mining industries and the innovation sector and sales of foreign assets in metallurgy;

- Growth in the role of prestigious jurisdictions in DFI movement abroad.

It would seem that strengthening of positions of Russian investors on the global level will be determined by sectorial and geographic diversification of their activities beyond the limits of traditional areas which are less dependent on the effect of external pricing factors and entry by the "second echelon" of Russian corporations, primarily, non-primary sector companies and financial sector companies, as well as innovation companies which represent mid-sized business to the global DFI market.

It is to be noted that investment expansion of the Russian business abroad will have a growing effect on the economic development of Russia and its foreign economic relations. The scale of the accumulated Russian investments (industrial and financial resources) abroad have reached the extent when those investments are transformed into a foreign segment of the Russian economy (about $\$ 400 b n$ ) where the factors of forward effect on the sphere of national reproduction and formation of a new model of Russia's participation in the globalizing economy are created.

The above trends point to strengthening of the investment aspect of Russia's deeper integration into the global economy. Due to the above, it is important to ensure coordination of the Russian investment policy on the international and national levels, as well as its inter- subordination to the internal development strategy and the policy pursued in other areas (foreign economic, social and innovation spheres).

With a consistent government policy pursued, the export of direct investments may become an important component in implementation of Russia's foreign economic strategy and a new factor of development of investment processes in the country. It is to be noted that the following key issues as raising of efficiency of management of foreign assets on the corporate level in a situation of growing global competition and strengthening of the feedback of the above foreign segment with the domestic economy are to be solved.

In the past few years, the research community is in search of a new economic growth model as the existing model aimed, in particular, at development of the primary sector's export has virtually exhausted its potential. Due to worsening of the situation in the economy, it is the issue of how to ensure a $4 \%$ growth that is on the top of the agenda, rather than the prospect of achievement of annual growth of 5-6\% ${ }^{1}$.

A particular attention is to be paid to the foreign economic component of economic development which accounted for $2.0 \%-2.5 \%$ of GDP growth in the pre-crisis period against less than $1 \%$ at present. Due to the above, it appears that the export of direct investments from the country may become an important factor behind implementation of the foreign economic policy of the Russian Federation and give a new impetus to the domestic economy.

1 See, for example, the Forecast of the Long-Term Social and Economic Development of the Russian Federation till 2030 (the Ministry of Economic Development of the Russian Federation) approved on March 25, 2013. 